\title{
TINGKAT KECERDASAN SPIRITUAL DAN KEMAMPUAN MENGHAFAL AL-QUR'AN
}

\author{
Marliza Oktapiani ${ }^{1}$ \\ ${ }^{1}$ Dosen Universitas Islam As-syafi' 'iyah \\ marlizaoktapiani.fai@uia.ac.id
}

\begin{abstract}
Abstrak
Menghafal al-Qur'an merupakan perbuatan yang mulia, menghafal al-Qur'an sangat mudah jika para calon penghafal mempersiapkan diri sebelum memulai menghafal al-Qur'an. Menghafal al-Qur'an juga akan menjadi lebih mudah jika penghafal memiliki hubungan yang baik kepada Allah Swt, dan menjaga hubungan kepada Allah Swt itu dengan meningkatkan ibadah, berakhlak yang baik, suka tolong menolong antar sesama, hal ini juga bisa disebut dengan meningkatkan kecerdasan spiritual. Menghafal Al-Qur'an pun perlu memperhatikan faktor-faktor pendukungnya, dengan cara menjaga kesehatan yang merupakan salah satu faktor yang sangat penting bagi orang yang akan menghafal al-Qur'an. Jika tubuh sehat maka proses menghafal akan menjadi lebih cepat tanpa adanya penghambat, dan batas waktu menghafalpun menjadi relatif cepat. Orang yang menghafal al-Qur'an sangat membutuhkan ketenangan jiwa, baik dari segi pikiran maupun hati. Untuk itu selain kesehatan lahiriah penghafal al-Qur'an juga memerlukan kesehatan dari segi psikologis. Karena, bila banyak yang dipikirkan atau dirisaukan oleh penghafal al-Qur'an maka proses menghafal akan terganggu, akibatnya akan banyak ayat yang sulit untuk dihafal. Ketika hal itu terjadi maka disarankan bagi penghafal alQur'an untuk memperbanyak berdzikir dan beristighfar kepada Allah Swt. Orang yang menghafal al-Qur'an pasti sangat membutuhkan motivasi dari orang-orang terdekat, kedua orang tua, keluarga, dan sanak kerabat. Dengan adanya motivasi ia akan lebih bersemangat dalam menghafal al-Qur'an. Kurangnya motivasi dari orang-orang terdekat atau dari keluarga akan menjadi salah satu faktor penghambat bagi penghafal itu sendiri.
\end{abstract}

Kata Kunci: Kecerdasan Spiritual, hafalan, Al-Qur'an

\section{Pendahuluan}

Al-Qur'an diturunkan untuk dijadikan petunjuk, bukan hanya untuk sekelompok manusia ketika ia diturunkan, tetapi juga untuk seluruh manusia hingga akhir zaman. Oleh karena itu, untuk menjaga keauntentikan al-Qur'an diperlukan penjagaan dan pemeliharaan agar umat Islam tidak kehilangan petunjuk, yaitu dengan membumikan alQur'an. Yang dimaksud dengan membumikan al-Qur'an disini yaitu melakukan upayaupaya yang terarah dan sistematis didalam masyarakat agar nilai-nilai al-Qur'an hidup dan dipertahankan.

Al-Qur'an merupakan kitab suci umat Islam yang sempurna. Di dalamnya terdapat perintah, larangan, peringatan, ancaman, kabar gembira, petunjuk, kisah penuh 
hikmah, dan lain-lain. Tidak mengherankan jika al-Qur'an menjadi sumber dan rujukan dalam mendalami berbagai macam ilmu.

Fungsi utama al-Qur'an adalah sebagai hidayah (petunjuk) bagi manusia dalam mengelola hidupnya didunia dengan baik, dan merupakan rahmat untuk alam semesta, disamping pembeda antara yang hak dan yang bathil, juga sebagai penjelas terhadap sesuatu, akhlak, moralitas dan etika-etika yang patut dipraktikkan manusia dalam kehidupan mereka. Penerapan semua ajaran Allah itu akan membawa dampak positif bagi manusia sendiri. (Nawawi dan Syauqi, 2011:240). Salah satu cara Allah Swt menjaga alQur'an yaitu Allah Swt telah memberikan kemudahan dalam menghafal serta mempelajarinya, sebagaimana firmanNya dalam Al-Qur'an :

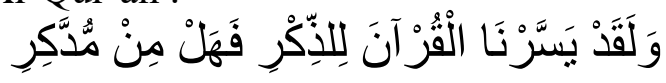

Dan sesungguhnya telah Kami mudahkan al-Qur'an untuk pelajaran, maka adakah orang yang mengambil pelajaran? (QS. Al-Qamar/54:17).

Dari ayat di atas Allah telah menjelaskan bahwa Allah yang menurunkan al-Qur'an dengan mempermudahkan pembacaan dan pengertiannya yang mengandung ibarat dan tamsil untuk dijadikan pelajaran bagi orang yang hendak merenungkannya. Tapi, kebanyakan para penghafal al-Qur'an hanya fokus menghafal saja, tanpa mendalami atau mengambil ibrah dalam al-Qur'an. Padahal Allah telah memberikan kemudahan dalam setiap membacanya serta mengambil pelajaran yang terkandung dalam al-Qur'an. Dahhak telah meriwayatkan bahwa Ibnu 'Abbas berkata : "Andai kata Allah tidak memudahkan al-Qur'an bagi lidah manusia niscaya tidak seorang pun dari manusia yang dapat berbicara dengan pembicaraan Allah" (Hafizh Dasuki, dkk, 1990:603).

Menghafal al-Qur'an adalah pekerjaan yang sangat mulia. Akan tetapi menghafal al-Qur'an tidaklah mudah seperti membalikkan telapak tangan. Oleh karena itu, ada hal-hal yang perlu dipersiapkan sebelum menghafal agar menghafal tidak begitu berat (Juju Saepudin, dkk. 2015:28). Salah satu faktor yang menyebabkan para penghafal alQur'an mengalami kesulitan, karena mereka tidak mempersiapkan diri dengan hal-hal yang terkait dalam menghafal al-Qur'an.

Melihat dari realita para penghafal al-Qur' an yang ada, kemudahan yang didapatkan setelah memenuhi hal-hal yang yang harus dipersiapkan sebelum menghafal di sini tidak hanya mencakup kemudahan dalam mengambil ibrah/pelajaran dalam al-Qur'an saja, namun juga mencakup kemudahan dalam membaca, memahami, mentadabburi, bahkan menghafalkan ayat-ayat suci tersebut (Al-Kahil, 2011:13).

Proses kemudahan ini bahkan diurai dalam al-Qur'an, lengkap dengan pengalaman Rasulullah Saw saat mencoba menghafalkannya. Petunjuk inilah yang kelak melahirkan para huffazh di muka bumi dalam setiap generasi, dari zaman old hingga zaman now. Berbagai metode bahkan ditemukan, menyajikan aneka menu yang memudahkan hafalan. Dari bacaan perhalaman hingga cara semudah senyuman. Semua berdasar pengalaman penghafal saat berinteraksi dengan al-Qur'an. Uniknya, seluruh interaksi ini akan mengacu pada satu petunjuk utama, hal yang menjadikan al-Qur'an begitu mudah dihafal. Bukan satu metode, tapi isyarat al-Qur'an tentang cara ia dihafal (Adi Hidayat, 2018: Xv). 
Demikian pula, selain al-Qur'an mudah untuk di hafal serta di pelajari maknanya, al-Qur'an juga telah berbicara tentang konsep membangun kecerdasan dengan penjelasan yang sangat gamblang dan sangat sederhana. Sedemikian gamblangnya sehingga kita hanya membutuhkan sedikit waktu untuk memahaminya dan sedemikian sederhananya sehingga kita akan mungkin untuk menerapkan aplikasinya dalam kehidupan sehari-hari ( Dedhi Suharto, Ak. 2006:120).

Berbicara tentang kecerdasan, tentu akan sangat erat hubungannya dengan otak. Kecerdasan pula yang membuat derajat manusia terangkat. Sayangnya, banyak orang bahkan para penghafal al-Qur'an mereka tidak mampu menggunakan kecerdasan secara optimal dalam kehidupan sehari-hari.

Hampir setiap orang menginginkan bisa memiliki otak yang cerdas dan super genius. Berbagai cara pun dilakukan untuk menjadikan otak cerdas yang fungsinya dapat dengan cepat memahami dan mengingat materi pelajaran. Tidak ada orang yang bodoh sekali di dunia ini, setiap orang memiliki kecenderungan, kelebihan dan potensinya masingmasing. Orang dikatakan cerdas ketika ia memiliki karakteristik yang khas, yang dapat membedakan dirinya dengan makhluk lain.

Seseorang yang akan menghafal al-Qur'an mesti bagus dan fasih dalam membaca al-Qur'an. Karena jika penghafal al-Qur'an tidak fasih dalam membaca al-Qur'an maka sudah barang tentu dia akan mengalami kesulitan-kesulitan dalam proses menghafal. Namun, dalam menghafal al-Qur'an bukan hanya tentang bagus bacaan dan hafalannya saja, melainkan juga harus terpuji akhlaknya karena ia adalah calon hamilul Qur'an. Jadi, sifat dan perilakunya mesti sesuai dengan semua yang diajarkan dalam al-Qur'an. Bisa menghafal al-Qur'an merupakan sebuah rahmat dan hidayah dari Allah Swt. Dan hal tersebut hanya bisa didapat oleh orang-orang yang mempunyai hati yang bersih (Alawiyah Wahid, 2013:39).

Melihat realita yang sekarang ini tidak sedikit para penghafal al-Qur'an memiliki akhlak yang kurang baik dikarenakan mereka hanya sekedar menghafal tapi tidak mengambil ibrah atau pelajaran didalam al-Qur'an.

Untuk itu dalam menghafal al-Qur'an juga, seorang penghafal al-Qur'an harus beriman dan bertakwa kepada Allah Swt melalui media shalat, melakukan semua perintahNya, dan menjauhi semua larangan-Nya. Jika seorang penghafal al-Qur'an tidak beriman dan bertakwa kepada Allah Swt, maka kesulitan-kesulitan dalam menghafal kalamullah ini akan selau menghadangnya. Hatinya akan gelap dan keruh, serta hanya memikirkan duniawi tanpa memikirkan hubungan interaksi dengan Allah Swt.

Jika tidak beriman dan bertakwa dengan sungguh-sungguh kepada Allah Swt, tidak akan ada jaminan bahwa seorang penghafal bisa menjalani proses menghafal al-Qur'an dengan lancar, bahkan menyelesaikannya. Para penghafal al-Qur'an yang tidak beriman serta bertakwa atau menjalin hubungan yang baik dengan Allah Swt maka mereka hanya akan mengalami kesulitan-kesulitan dalam menghafal ayat-ayat Allah Swt. Sebab, hati dan pikiran jauh dari Allah, serta jauh dari hati dan pikiran yang jernih. Bila hati dan pikiran yang jernih dan dekat dengan Allah Swt, seorang penghafal akan lebih mudah dalam menghafal ayat-ayat Allah. Orang yang jauh dari Allah Swt, hati dan pikirannya akan 
terasa kosong karena tidak ada kegiatan yang berhubungan denga ruhaninya. (Alawiyah Wahid, 2013:121)

\section{Pembahasan}

\section{Pengertian Kecerdasan Spiritual dan Menghafal Al-Qur'an}

Secara bahasa, kecerdasan mengandung arti "kesempurnaan akal budi"(Tim penyusun Pusat Bahasa,KBBI). Menurut Marthen Pali dalam buku karya Darma Putra (2018:104) kecerdasan merupakan keseluruhan kemampuan seorang untuk berfikir dan bertindak secara terarah, serta megolah dan menguasai lingkungan secara efektif. Sedangkan spiritual berasal dari kata "spirit" yang diartikan sebagai kekuatan, tenaga, semangat, vitalitas, energi, dan diposisi. Secara utuh, Chaplin mengatakan bahwa spiritual memiliki kaitan dengan roh, semangat jiwa (James P. Chaplin, 2009 : 480).

Kecerdasan spiritual menurut Danah Zohar dan Ian Marshall, sebagaimana yang dikutip oleh Ary Ginanjar adalah kecerdasan untuk menghadapi dan memecahkan persoalan makna dan value, yaitu kecerdasan untuk menempatkan perilaku dan hidup dalam konteks makna yang lebih luas dan kaya, kecerdasan untuk menilai bahwa tindakan atau jalan hidup seseorang lebih bermakna dibandingkan dengan yang lain (Ary Ginanjar Agustian, 2008 : 13).

Kemampuan adalah suatu karakteristik yang menonjol dari seorang individu yang berhubungan dengan kinerja efektif dan superior dalam suatu pekerjaan atau situasi (Hamzah B Uno, 2010:129). Menghafal dalam Kamus Besar Bahasa Indonesia (KBBI), disebutkan berasal darikata hafal yang artinya telah masuk diingatan, dapat mengucapkan diluar kepala (tanpa melihat buku dan yang lain-lain). Sedangkan menghafal artinya berusaha meresapkan ke pikiran agar selalu ingat.

Secara istilah, ada beberapa pengertian menghafal menurut para ahli : Baharudin, menghafal adalah menanamkan asosiasi kedalam jiwa (Baharudin, 2010:113), Syaiful Bahri Djamarah, mengahafal adalah kemampuan jiwa untuk memasukkan (learning), menyimpan (retention), dan menimbulkan kembali (remembering) hal-hal yang telah lampau (Syaiful Bahri D, 2008:44). Kata "al-Qur'an" berasal dari kata "qara'a” yang berarti mengumpulkan, mengabulkan, dan membaca, yakni menggabungkan hurufhuruf dan kata-kata dengan yang lain. Al-Qur'an adalah firman Allah Swt yang diturunkan kepada Nabi Muhammad Saw yang memiliki keutamaan-keutamaan, diantaranya: diriwayatkan secara mutawatir, membacanya adalah ibadah, dan dijadikan tantangan bagi orang-orang yang pandai berbahasa Arab untuk menandingi walaupun surat terpendek dari al-Qur'an (Nina Aminah, 2013:25).

Sedangkan al-Qur'an menurut Abdul Djalal adalah kalam Allah yang Mu'jiz, diturunkan kepada Nabi dan Rasul penghabisan dengan perantara malaikat Jibril, tertulis dalam mushaf yang dinukilkan kepada kita secara mutawatir, membacanya merupakan ibadah, yang di awali dari surah Al-Fatihah dan di akhiri dengan surah An-Nas (Abdul Djalal, 2000:11). Kegiatan menghafal al-Qur'an juga merupakan sebuah proses mengingat seluruh materi ayat (rincian bagian-bagiannya, seperti fonetik, waqaf, dan lain-lain) harus dihafal dan diingat secara sempurna (Wiwi 
Alawiyah W, 2012:15). Sebagaimana yang kita ketahui, al-Qur'an merupakan bacaan yang mulia, kitab yang terpelihara tidak ada yang menyentuhnya kecuali orang-orang yang suci (Mana'ul Quthan, 1993:11). Tidak ada satu bacaan apapun selain al-Qur'an, yang dipelajari redaksinya. Bukan hanya segi penempatan kata demi kata dalam susunannya bahkan dalam pemeliharaan kata tersebut, tetapi mencakup arti kandungannya yang tersurat dan tersirat sampai kepada kesan-kesan yang ditimbulkannya (M. Quraish Syihab, 2013:21).

Untuk itu, setiap orang yang ingin menghafal al-Qur'an harus mempunyai persiapan-persiapan yang matang agar proses hafalan dapat berjalan dengan baik dan benar. Selain itu, persiapan ini merupakan syarat yang harus dipenuhi supaya hafalan yang dilakukan bisa memperoleh hasil yang maksimal dan memuaskan (Wiwi Alawiyah W, 2012:28).

\section{Manfa'at Menghafal Al-Qur'an}

Menghafal al-Qur'an mengandung begitu banyak manfa'at, adapun manfaat menghafal al-Qur'an menurut Al-Kahil (2010:19) yaitu:

a. Al-Qur'an adalah kalam Allah dan menghafalnya merupakan aktivitas yang nilainya sangat besar dan dapat membuka pintu-pintu kebaikan.

b. Menghafal al-Qur'an diibaratkan menghafal kamus terbesar dunia, sebab alQur'an berisi tentang ilmu dunia dan akhirat, juga tentang kisah orang-orang terdahulu dan yang akan datang, tentang hukum dan perundang-undangan serta syari'at yang menbgatur seorang mukmin.

c. Al-Qur'an merupakan obat bagi penyakit jiwa.

d. Dengan menghafal al-Qur'an waktu yang dimiliki manusia tidak akan terbuang sia-sia.

Sementara itu, Wiwi Alawiyah Wahid (2012:145) menuliskan dalam bukunya manfaat dan keutamaan menghafal al-Qur' an menurut Imam Nawawi dalam kitab AtTibyan Fi Adabi Hamalati al-Qur'an, diantaranya yaitu :

a. Al-Qur'an adalah pemberi syafa'at pada hari kiamat bagi umat manusia yang membacanya, memahami, dan mengamalkannya.

b. Para penghafal al-Qur'an telah dijanjikan derajat yang tinggi disisi Allah. Pahal yang besar serta penghormatan di antara manusia.

c. Al-Qur'an menjadi hujjah dan pembela bagi pembacnya serta sebagai pelindung dari siksaan api neraka.

d. Para pembaca al-Qur'an khususnya para penghafal al-Qur'an yang kualitas dan kuantitas bacaannya lebih bagus akan bersama malaikat yang selalu melindunginya dan mengajak pada kebaikan.

e. Para penghafal al-Qur'an diprioritaskan untuk menjadi imam dalam shalat.

f. Penghafal al-Qur'an adalah pilihan Allah Swt.

g. Para penghafal al-Qur'an adalah orang-orang yang mulia dari umat Rasulullah Saw.

h. Menghafal al-Qur'an salah satu kenikmatan paling besar yang telah diberikan oleh Allah Swt. 
i. Mencintai penghafal al-Qur'an sama dengan mencintai Allah Swt.

j. Para penghafal al-Qur'an memiliki ingatan yang tajam dan bersih intuisinya.

k. Para penghafal al-Qur'an telah banyak menghafal kosa kata bahasa arab.

1. Kehormatan dan kemuliaan yang diberikan oleh Allah Swt, tidak hanya kepada sang penghafal al-Qur'an saja melainkan juga bagi kedua orang tuanya.

m. Menghafal al-Qur'an mempunyai manfaat akademis, al-Qur'an merupakan pengetahuan dasar bagi para thalabul 'ilmi dalam proses belajarnya. Apabila ia menghafal al-Qur'an maka ia akan memberikan kontribusi yang sangat besar terhadap studinya, sebab al-Qur'an merupakan sumber ilmu.

\section{Persiapan-Persiapan dalam Menghafal Al-Qur'an}

Setiap orang yang akan menghafal al-Qur'an mesti mempunyai persiapan yang matang agar proses menghafal dapat berjalan dengan baik dan benar. Berikut beberapa persiapan yang harus ada pada para penghafal, diantaranya :

a. Niat yang Ikhlas

Bagi seseorang penghafal al-Qur'an wajib baginya untuk melandasi hafalannya dengan niat yang ikhlas (Wiwi Alawiyah W, 2012:28). Karena menghafal al-Qur'an adalah bagian dari ibadah, sedangkan ibadah membutuhkan hadirnya keikhlasan. Karena itu, para penghafal al-Qur'an mesti meniatkan hafalannya karena Allah Swt semata (Adi Hidayat, 2018:12). Sebagaimana yang diterangkan dalam sebuah hadits :

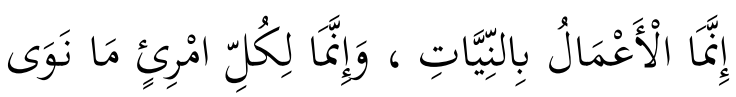

Sesungguhnya amal-amal itu hanya dengan niat, seseorang akan mendapatkan sesuai dengan niatnya. (HR. Al-Bukhari dan Muslim).

Jika tanpa dilandasi niat yang ikhlas maka menghafal al-Qur'an akan menjadi sia-sia belaka.

b. Meminta Izin Orang Tua

Semua anak yang hendak mencari ilmu atau menghafal al-Qur'an, sebaiknya terlebih dahulu meminta izin kepada kedua orang tuanya. Sebab, hal itu akan berpengaruh terhadap keberhasilan menghafal al-Qur'an (Wiwi Alawiyah W, 2012:30).

Dengan meminta izin terlebih dahulu kepada kedua orang tua, apabila suatu saat para penghafal mengalami kesulitan atau permasalahan saat menghafal alQur'an, maka mereka akan mendapatkan motivasi dan do'a dari mereka. Do'a tersebut akan sangat berperan untuk kelanjutan dan kelancaran dalam proses menghafal.

c. Mempunyai Tekad yang Kuat

Ketika Nabi Muhammad Saw akan meraih ayat al-Qur'an, beliau begitu bersemangat hingga mendaki gunung cahaya menuju gua hira. Semangat serta kesungguhan beliau mampu menaklukkan jarak dan dakian yang begitu tinggi (Adi Hidayat, 2018:13). 
Seseorang yang hendak menghafal al-Qur'an wajib memiliki tekad atau kemauan yang besar dan kuat. Dengan adanya tekad yang besar dan kuat dan terus berusaha untuk menghafalkan al-Qur'an, maka segala macam ujian insya Allah akan bisa dilalui dan dihadapi (Wiwi Alawiyah W, 2012:31).

Sejalan dengan hal itu, Allah berfirman dalam QS. Al-Isra' 17:19 :

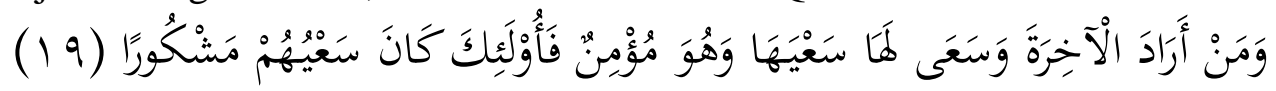

Dan barangsiapa menghendaki kehidupan akhirat dan berusaha ke arah itu dengan sungguh-sungguh, sedanhkan dia beriman, maka mereka itulah yang usahanya dibalas dengan baik. (QS. Al-Isra'/17:19)

\section{d. Sabar}

Sabar merupakan kunci kesuksesan untuk meraih cita-cita, termasuk cita-cita dan keinginan untuk menghafal al-Qur'an, kesulitan akan dihadapi jika tidak mempunyai sifat sabar dalam menghafal al-Qur'an. Sabar mutlak diperlukan oleh setiap penghafal al-Qur'an. Hafalan yang dijalani dengan kesabaran cenderung baik dan tartil (Adi Hidayat, 2018:14).

Sifat sabar juga cenderung mendekatkan hamba dengan Allah Swt. Innallaha ma'as shabirin, Allah bersama para penyabar. Demikian kiranya kedekatan itu dilukis dalam al-Qur'an. Kedekatan inilah yang akan melahirkan kekhusyuan dalam bacaan bahkan cenderung meningkatkan keimanan. Karena itu, Allah Swt memberi kegembiraan khusus pada orang yang sabar terlebih saat menjalani ujian.

e. Berguru pada yang Ahli

Seseorang yang menghafal al-Qur'an harus berguru kepada yang ahlinya, yaitu guru tersebut harus seorang yang hafal al-Qur'an serta seorang yang sudah mantap dalam segi agama dan pengetahuannya tentang al-Qur'an.

Ini penting diperhatikan karena al-Qur'an diturunkan pada Rasulullah Saw dengan proses bimbingan, langsung dari malaikat Jibril 'alaihissalam. Demikian pula Rasulullah menjadi pembimbing para shabatnya dalam menghafal, memahami, serta mengamalkan kandungan al-Qur'an.

f. Memiliki Akhlak yang Terpuji

Seperti dimaklumi bahwa misi utama kehadiran Nabi Muhammad Saw adalah membangun kualitas moral (akhlaq al-karimah), dalam hadits yang sangat popular, Rasulullah Saw menegaskan misi utamanya beliau diutus oleh Allah Swt, yakni menyempurnakan akhlaqul karimah (Ilyas Ismail, 2013:23).

Oleh karena itu, sangat penting meneladani akhlak Rasulullah Saw. Terutama bagi para penghafal al-Qur'an, karena orang yang menghafal al-Qur'an bukan hanya harus bagus bacaan dan hafalannya, melainkan juga harus terpuji akhlaknya. Sebab hafalan al-Qur'an tidak akan bertahan lama di hati orang-orang yang sering atau sibuk melakukan sesuatu yang tidak terpuji atau maksiat (Wiwi Alawiyah W, 2012: 39). 
g. Berdo'a kepada Allah

Para penghafal al-Qur'an dianjurkan untuk memperbanyak berdo'a khususnya dalam waktu-waktu mustajab, agar Allah berkenan menjaga ayat-ayat suci dalam dirinya serta mampu mengamalkannya dalam kehidupan. Adapun waktu-waktu mustajab untuk berdo'a ialah, saat-saat sujud, sepertiga malam terakhir, juga pasca muraja'ah ialah diantara momentum terbaik dalam berdo'a (Adi Hidayat, 2018:34).

h. Menggunakan Satu Jenis Al-Qur'an

Para penghafal al-Qur'an sangat dianjurkan untuk menggunakan al-Qur'an yang sama atau satu jenis. Janganlah berganti-ganti al-Qur'an dari mulai proses menghafal sampai hatam 30 juz (Wiwi Alawiyah W, 2012:48).

Alangkah baiknya jika pembaca menemukan mushaf yang didisain khusus untuk hafalan (Adi Hidayat, 2018:26).

i. Istiqomah

Dalam proses menghafal al-Qur'an, istiqomah sangat penting, walaupun seseorang memiliki kecerdasan yang tinggi, namun jika tidak istiqamah maka akan kalah dengan orang yang kecerdasannya biasa-biasa saja tetapi istiqomah (Wiwi Alawiyah W, 2012:35).

Sikap istiqomah ialah diantara faktor yang amat menentukan dalam meneguhkan hafalan. Sedikit namun konsisten lebih baik dibanding banyaknya hafalan yang tidak teratur. Demikian isyarat umum yang tampak dalam nasehat umum Nabi Muhammad SAW riwayat sayyidah Aisyah :

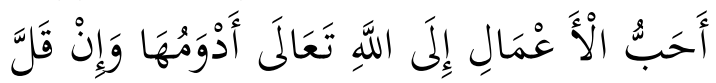

Amal yang paling dicintai Allah Ta'ala ialah yang konsisten sekalipun itu sedikit. (HR. Muslim).

\section{Faktor Pendukung Dalam Menghafal Al-Qur'an}

Banyak faktor seseorang mempunyai alasan untuk terus dapat menghafal alQur'an, Wiwi Alawiyah Wahid (2012:139) membagi faktor pendukung dalam menghafal al-Qur'an menjadi lima faktor, diantaranya:

a. Faktor Kesehatan

Kesehatan merupakan salah satu faktor yang sangat penting bagi orang yang akan menghafal al-Qur'an. Jika tubuh sehat maka proses menghafal akan menjadi lebih cepat tanpa adanya penghambat, dan batas waktu menghafalpun menjadi relatif cepat.

b. Faktor Psikologis

Orang yang menghafal al-Qur'an sangat membutuhkan ketenangan jiwa, baik dari segi pikiran maupun hati. Untuk itu selain kesehatan lahiriah penghafal al-Qur'an juga memerlukan kesehatan dari segi psikologis. Karena, bila banyak yang dipikirkan atau dirisaukan oleh penghafal al-Qur'an maka proses menghafal 
akan terganggu, akibatnya akan banyak ayat yang sulit untuk dihafal. Ketika hal itu terjadi maka disarankan bagi penghafal al-Qur'an untuk memperbanyak berdzikir dan beristighfar kepada Allah Swt.

c. Faktor Kecerdasan

Kecerdasan merupakan salah satu faktor pendukung dalam proses menghafal al-Qur'an. Setiap individu memiliki kecerdasan yang berbeda-beda, sehingga cukup mempengaruhi terhadap proses hafalan yang dijalani.

Namun, perlu digaris bawahi kurangnya kecerdasan bukan berarti menjadi alasan untuk tidak bersemangat dalam proses menghafal al-Qur'an. Hal yang terpenting adalah rajin dan istiqomah dalam menjalani hafalan serta bangun hubungan yang baik dengan Allah Swt.

d. Faktor Motivasi

Orang yang menghafal al-Qur'an pasti sangat membutuhkan motivasi dari orang-orang terdekat, kedua orang tua, keluarga, dan sanak kerabat. Dengan adanya motivasi ia akan lebih bersemangat dalam menghafal al-Qur'an. Kurangnya motivasi dari orang-orang terdekat atau dari keluarga akan menjadi salah satu faktor penghambat bagi penghafal itu sendiri.

Namun, jika penghafal al-Qur'an kurang mendapatkan motivasi dari luar (keluarga dan kerabat), maka para peghafal al-Qur'an harus menghadirkan motivasi terbaik untuk dirinya sendiri, agar dapat mengembalikan semangat sekaligus menepikan pelbagai situasi yang membuat hilangnya motivasi menghafal (Adi Hidayat, 2018:19). Diantara motivasi terbaik yang pernah disampaikan Nabi Saw ialah :

1) Penghafal al-Qur'an akan meraih kemuliaan surga

2) Penghafal al-qur'an akan menjadi hamba terbaik

3) Penghafal al-Qur'an akan mendapatkan limpahan pahala

e. Faktor Usia

Pada dasarnya, mencari ilmu tidaklah mengenal waktu dan usia, begitupun dengan menghafal al-Qur'an. Menghafal al-Qur'an bisa dilakukan kapan saja dan oleh usia berapapun. Namun, tidak bisa dipungkiri juga, kalu semakin dewasa usia seseorang maka pikirannya akan semakin kompleks dalam permasalahan. Dengan alasan itulah, usia yang dianjurkan untuk menghafal al-Qur'an adalah mereka yang masih menempuh usia produktif.

Indikator Meningkatkan Kecerdasan Spiritual dengan Menghafal Al-Qur'an

Menghafal al-Qur'an pada prinsipnya adalah proses mengulang-ulang bacaan alQur'an, baik dengan membaca ataupun mendengarkan. Tujuannya agar ayat-ayat yang terkandung dalam al-Qur'an itu lebih melekat pada ingatan sang penghafal.

a. Membaca sebelum menghafal al-Qur'an

Membaca adalah suatu kegiatan interaktif untuk memetik serta memahami arti atau makna yang terkandung dalam bahan tulis (Samasu Somadayo, 2011:4).

Sebelum menghafal al-Qur'an sangat dianjurkan agar sang penghafal lebih dahulu lancar dalam membaca al-Qur'an. Sebab kelancaran dalam membacanya dapat mempercepat dalam menghafal (Wiwi Alawiyah W, 2012:52). 
Tujuan memperbanyak membaca sebelum menghafal al-Qur'an adalah agar penghafal mengenal terlebih dulu ayat-ayat tersebut, sehingga lebih mudah dalam menghafalkannya (Wiwi Alawiyah W, 2012:102).

b. Menyimakkan hafalan al-Qur'an

Semaan al-Qur'an atau Tasmi' (memperdengarkan hafalan kepada orang lain), misalnya kepada sesama teman tahfidz atau kepada senior yang lebih lancar merupakan hal yang sangat positif. Sebab, kegiatan tersebut merupakan salah satu metode untuk tetap memelihara hafalan supaya tetap terjaga (Wiwi Alawiyah Wahid, 2012:98).

c. Mendengarkan hafalan al-Qur'an

Mendengarkan adalah salah satu aktivitas dalam belajar, dalam hal ini yang dimaksud dengan mendengarkan adalah mendengarkan hafalan dari orang-orang yang yang sedang menghafal al-Qur'an, dan mendengarkan melalui kaset-kaset atau rekaman hafalan al-Qur'an. Cara ini dapat dilakukan dengan mendengarkan bacaan para huffadz di waktu mereka sedang membaca (sima'an).

d. Mengulang hafalan al-Qur'an

Dalam mengulang hafalan yang baik, hendaknya mengulang yang sudah dihafal atau sudah disetorkan kepada guru atau kiai secara terus menerus dan istiqomah. Tujuan dari takrir atau mengulang hafalan ialah supaya hafalan yang sudah dihafalkan tetap terjaga dengan baik, kuat, dan lancar (Wiwi Alawiyah Wahid, 2012:77). Sesuai sabda Nabi Saw :
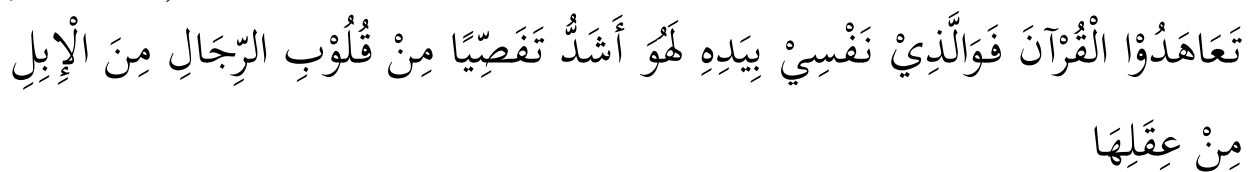

Jagalah al-Qur'an, demi yang jiwaku ada ditangan-Nya, al-Qur'an itu lebih cepat lepas dari hati para penghafalnya daripada lepasnya seekor unta dari ikatannya. (HR.Bukhari).

\section{Fungsi Kecerdasan Spiritual terhadap Kemampuan Menghafal}

Kecerdasan spiritual memberikan banyak kesempatan atau kecerdasan untuk berbuat disertai dengan rasa cinta yang melahirkan tanggung jawab, dengan menempatkan rasa cinta kepada Allah Swt sebagai kebenaran yang tertinggi (Darmiyati Zuchdi, 2012:108).Kecerdasan spiritual juga telah ada sejak manusia dilahirkan ini disandarkan pada proses peniupan ruh pada jasad manusia oleh Tuhan yang diikuti nilai-nilai spiritual Tuhan (sifat-sifat Tuhan) kedalam jasad manusia tersebut. Sehingga dengan demikian tidak ada manusia yang tidak memiliki nilai-nilai spiritual, akan tetapi nilai spiritual ini masih berupa potensi yang perlu dikembangkan lebih lanjut (Dakir dan Sardimi, 2011: 56). Siti A. Toyibah, dkk. (Jurnal Psikologi Islam, No. 2, 2017: 191-204) menyatakan bahwa kecerdasan spiritual ini sesuatu yang dapat diubah dan ditingkatkan, sehingga manusia dapat meningkatkan kecerdasan spiritual yang dimilikinya sampai usia tua. 
Kecerdasan spiritual dari sudut pandang psikologi memiliki fungsi dapat membangkitkan "God Spot" yang ada pada otak manusia (Abdullah Hadziq, 2012:29). God Spot (titik Tuhan) merupakan titik spiritual yang terletak diantara hubungan-hubungan saraf dalam cuping-cuping temporal otak (Danah Zohar dan Ian Marshall, 2002:10). Pada God Spot inilah sebenarnya terdapat fitrah manusia yang terdalam. Kajian tentang God Spot inilah yang melahirkan konsep kecerdasan spiritual, yakni kemampuan manusia yang berkenaan dengan usaha memberikan penghayatan bagaimana agar hidup lebih bermakna (Ary Ginanjar Agustian, 2001 :7).

Ary Ginanjar Agustian (2001:12) menyebutkan ada 7 faktor yang mempengaruhi fitrah (God Spot) yang secara tidak langsung juga mempengaruhi kecerdasan spiritual seseorang, yaitu : Prasangka, Prinsip-prinsip hidup, Pengalaman, Kepentingan dan prioritas, Sudut pandang, Pembanding, dan Literatur . Kecerdasan bercirikan sejumlah karakter, yakni: pluck (berani), optimism (besar hati), faith (keimanan), contructive action (tindakan memperbaiki), even agility in the face danger (kecerdasan dalam menghadapi bahaya), dan all these are spiritual traits (semua sifat rohaniah), (Zubaedi, 2011:53).

Manusia yang mencapai kematangan spiritual akan lebih menyukai persahabatan dengan semuanya. Selain itu, manusia tersebut sangat disukai oleh orang-orang disekitarnya, karena manusia yang telah matang spiritualnya ini mampu memberikan angin segar yang menyejukkan orang-orang di dekatnya. Mereka yang memiliki kecerdasan spiritual, tidak akan memiliki perasaan putus asa ataupun lelah dalam kegiatan yang dilakukannya. Hal ini karena terintegrasi prinsip kepada Allah Swt dan karena Allah Swt (Dakir dan Sardimi, 2011: 69-70).

Karakteristik anak yang mempunyai kecerdasan spiritual secara lebih rinci dapat dilihat dari indikator sebagai berikut :

a. Merasakan Kehadiran Allah Swt

Mereka yang bertanggung jawab dan cerdas secara ruhaniah, merasakan kehadiran Allah dimana saja mereka berada. Mereka meyakini bahwa salah satu produk dari keyakinannya dalam beragama anatara lain melahirkan kecerdasan spritual yang menumbuhkan perasaan yang sangat mendalam (zauq) bahwa dirinya senantiasa berada dalam pengawasan Allah (Toto Tasmara, 2001:14).

Allah Swt berfirman dalam QS. Qaaf ayat 16 :

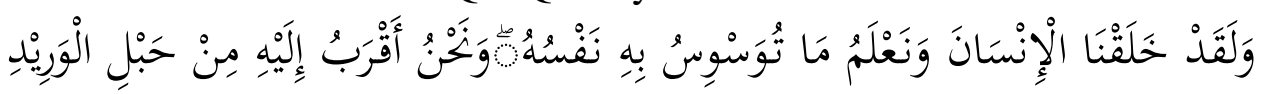

Dan sesungguhnya Kami telah menciptakan manusia dan mengetahui apa yang dibisikkan oleh hatinya, dan Kami lebih dekat kepadanya daripada urat lehernya. (QS.Qaaf/50:16) 
Ayat diatas menjelaskan bahwa Allah Swt senantiasa ada dimanapun hambanya berada dan tampak dalam pandangan batin yaitu qalbu.

Kesadaran bahwa Allah senantiasa bersamanya merupakan bentuk fitrah manusia. Dengan kesadaran itu pula, sebenarnya nilai-nilai moral akan terpelihara.

b. Senang Menolong Orang Lain

Anak yang mempunyai kecerdasan spiritual yang tinggi akan senantiasa berbuat baik. Hal ini dibuktikan dengan sikapnya yang senang menolong orang lain (Akhmad Muhaimin Azzed, 2014:52). Karena dalam dirinya telah tumbuh rasa empati yang memungkinkan anak untuk dapat merasakan kondisi batin orang lain (Toto Tasmara, 2001:30). Allah berfirman dalam QS. Qt-Taubah ayat 128:

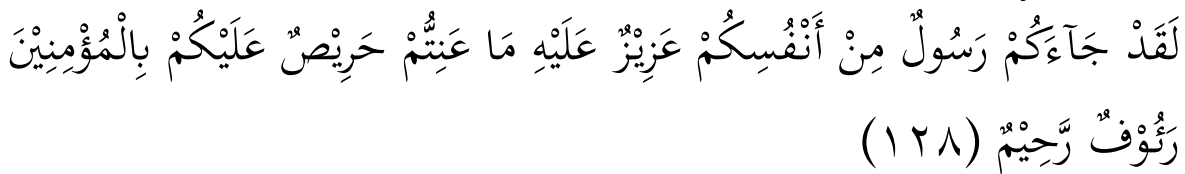

Sesungguhnya telah datang kepadamu seorang Rasul dari kaummu sendiri, berat terasa olehnya penderitaanmu, sangat menginginkan (keimanan dan keselamatan) bagimu, amat belas kasihan lagi penyayang terhadap orang mukmin. (QS. At-Taubah/9:128)

Setidaknya ada tiga cara dalam menolong orang lain, yakni menolong dengan kata-kata, menolong dengan tenaga, dan menolong dengan barang (baik itu berupa makanan, obat-obatan, uang atau harta benda lainnya),(Akhmad Muhaimin Azzed, 2014:49).

c. Bertanggung Jawab

Dalam Islam, pertanggung jawaban merupakan salah satu dasar dari keyakinan agama. Hal ini persis seperti hukum aksi-reaksi atau hukum sebab akibat yang bersifat universal. Setiap manusia harus bertanggung jawab terhadap apa yang dimilikinya, maupun segala yang dilakukannya (Syahmurhanis dan Harry S, 2006:176). Hal ini sesuai dengan firman Allah Swt dalam al-Qur'an surat Al-Isra' ayat 36:

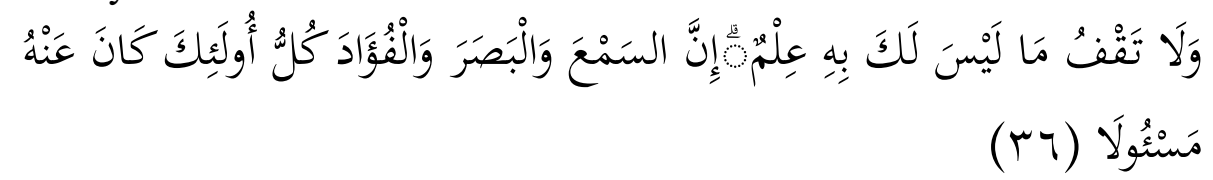

Dan janganlah kamu mengikuti apa yang kamu tidak mempunyai pengetahuan tentangnya. Sesungguhnya pendengaran, penglihatan dan hati, semuanya itu akan dimintai pertanggung jawaban. (QS. Al-Isra'/17:36)

d. Jujur

Kejujuran adalah tiang penopang segala persoalan. Salah satu dimensi kecerdasan ruhani terletak pada nilai kejujuran yang merupakan mahkota 
kepribadian orang-orang yang mulia. Kejujuran merupakan komponen rohani yang menentukan beragi sukap terpuji (Toto Tasmara, 2001:189-190).

Secara filosofis, sikap jujur ditanamkan Allah kepada setiap umat-Nya melalui pemahaman bahwa Allah menyediakan malaikat-malaikat yang mengikuti manusia mencatat segala amal perbuatannya (Syahmurhanis dan Harry S, 2006:172). Anak-anak yang mempunyai kesadaran dini mempersiapkan diri untuk menempuh jalan yang jelas karena merasakannya sebagai bagian yang ditakdirkan untuk di emban dalam hidupnya. Pengetahuan itu memberi mereka beberapa langkah lebih maju tentang kejujuran (Marsha Sinetar, 2000:Xiv)

e. Disiplin dan Sungguh-sungguh

Menghargai waktu dan bersikap sungguh-sungguh dalam mengerjakan kebaikan merupakan ciri-ciri Muslim yang memiliki kecerdasan spiritual yang tinggi (Syahmurhanis dan Harry S, 2006:178).

Disiplin adalah suatu tata tertib yang dapat mengatur tatanan kehidupan pribadi dan kelompok. Disiplin timbul dari dalam jiwa karena adanya dorongan untuk menaati tata tertib tersebut (M. Abdul Qadir, 2006:149).

\section{Penutup}

Menghafal al-Qur'an merupakan suatu aktivitas yang sangat mulia. Itulah sebabnya, orang yang mampu menghafal al-Qur'an akan mendapatkan karunia yang istimewa dan luar biasa. Menghafal al-Qur'an memang memakan waktu yang relatif panjang dan tidak mudah. Dikatakan tidak mudah karena ketika akan menghafal seseorang harus memiliki persiapan yang matang. Buktinya sudah banyak di Indonesia sendiri orang-orang yang telah berhasil menghafal al-Qur'an. Dan jika seseorang banyak yang merasa gagal dalam menghafal al-Qur'an berarti mereka kurangnya persiapan diri. Selain itu juga para penghafal mesti memperbanyak berdo'a kepada Allah Swt agar diberi kemudahan dalam menghafal ayat-ayat-Nya. Karena tidak sedikit ayat-ayat yang memiliki kemiripan dengan ayat yang lain, demikian juga kalimatnya yang panjang-panjang.

Penghafal al-Qur'an juga wajib menjaga hafalannya, memahami apa yang terkandung dalam al-Qur'an serta bertanggung jawab untuk mengamalkannya. Oleh karena itu menghafal al-Qur'an dikatakan memakan waktu yang relatif panjang. Adapun persiapan yang harus di matangkan bagi penghafal al-Qur'an agar sukses menghafal diantaranya ialah : niat yang ikhlas, tekad yang kuat, sabar, memperbaiki akhlak, istiqomah serta selalu berdo'a kepada Allah Swt. Kecerdasan spiritual merupakan satu hal yang dapat mempengaruhi dalam menghafal al-Qur'an. Sebab, dalam menghafal al-Qur'an para penghafal harus membangun hubungan yang baik dengan Allah Swt, agar proses menghafal menjadi lebih mudah serta dapat menyelesaikannya dalam waktu yang tidak terlalu panjang. Dan dalam menghafal juga diperlukan kesabaran dan keistiqomahan serta tekunan agar hafalannya sempurna meskipun permasalahan yang sering menghinggapi para penghafal al-Qur'an ialah terlalu fokus menghafal tapi kurang menjalin hubungan yang baik kepada Allah Swt serta kurang berdo'a, apalagi pada waktu-waktu yang mustajab. 


\section{Daftar Pustaka}

Abu Faris, M. A,Q. (2006). Menyucikan Jiwa, Jakarta: Gema Insani.

Agustian Ary, G. (2008). ESQ, Emotional Spiritual Quotient, Jakarta : Arga Publishing. Alawiyah wahid, W. (2012). Cara Cepat Menghafal Al-Qur'an, Jogjakarta:DIVA Press Al-Kahil, Abdud Daim. (2010). Hafal Al-Qur'an tanpa Nyantri. Solo: Pustaka Arafah.

Aminah, N. (2013). Pendidikan Kesehatan dalam Al-Qur'an, Bandung:PT. Remaja Rosdakarya.

Dasuki, H, dkk. (1990). Al Qur'an dan Tafsirnya Jilid IX. Yogyakarta: PT. Dana Bhakti Wakaf.

Djalal A. (2000). Ulumul Qur'an, Surabaya:Dunia Ilmu.

Hidayat Adi, (2018). Muslim Zaman Now 30 Hari Hafal Al-Qur'an Metode At Taisir, Bekasi Selatan : Institut Quantum Akhyar.

Mahmud, M. (2016). Ketika Baca Al-Qur'an Begitu Mencerdaskan, Jakarta: PT.Serambi Semesta Distribusi.

Meggit, Carolyn. (2013). Memahami Perkembangan Anak, Jakarta: PT. Indeks.

Muhammad, S,A. (2017). Menghafal Al-Qur'an, Jakarta: PT.Qaf Media Kreativa.

Muhaimin Azzed A. (2014). Mengembangkan Kecerdasan Spiritual bagi Anak, Jogjakarta: Ar-Ruzz Media.

Nata, A. (2013). Pemikiran Pendidikan Islam dan Barat, Jakarta : Rajawali Pers, Cet. Ke2

Nawawi, Rif'at Syauqi (2011). Kepribadian Qur'ani, Jakarta: Amzah.

Quthan M. (1993). Pembahasan Ilmu Al-Qur'an I, Jakarta:Rineka Cipta.

Sinetar, M. (2000). Spiritual Intelligence, Kecerdasan Spiritual: Belajar dari Anak yang Mempunyai Kesadaran Diri, Jakarta: PT. Gramedia.

Soefandi, I. \& Pramudya, A. (2009). Strategi Mengembangkan Potensi Kecerdasan Anak, Jakarta:Bee Media Indonesia.

Sukidi, (2002). Rahasia Sukses Hidup Bahagia Kecerdasan Spiritual mengapa SQ Lebih Penting daripada IQ dan EQ, Jakarta: PT Gramedia Pustaka Utama

Tasmara, T. (2001). Kecerdasan Ruhaniah, (Transendental Intelligence), Membentuk Kepribadian yang Bertanggung Jawab, Profesional dan Berakhlak, Jakarta: Gema Insani.

Toyibah, Siti A, 2017. "Pengaruh Kecerdasan Spiritual Terhadap Psikologis Pada Mahasiswa Penghafal Al Qur'an”, Psikologi Islam, Vol 4, No. 2

Yusuf, S. (2014). Psikologi Perkembangan Anak dan Remaja, Bandung: PT Remaja Rosdakarya

Zamani, Z.\&Maksum, S.M. (2014). Metode Cepat Menghafal Al-Qur'an. Jakarta: Al-Barokah.. 